\title{
Developing Walvis Bay Port into a logistics gateway for southern Africa: Issues, challenges and the potential implications for Namibia's future
}

\begin{abstract}
Authors:
Christopher J. Savage ${ }^{1,2}$

Logan Fransman ${ }^{1,2}$

Andrew K. Jenkins ${ }^{3}$

Colin G. Bamford ${ }^{3}$

\section{Affiliations:}

${ }^{1}$ Namibian German Centre

for Logistics, Windhoek,

Namibia

${ }^{2}$ Polytechnic of Namibia

Windhoek, Namibia

${ }^{3}$ Business School, University of Huddersfield, United Kingdom
\end{abstract}

\section{Correspondence to:}

Logan Fransman

\section{Email:}

Ifransman@polytechnic.edu.na

\section{Postal address:}

Private Bag 13388, Windhoek

West, Namibia

\section{Dates:}

Received: 07 Aug. 2014 Accepted: 29 Sept. 2014 Published: 10 Dec. 2014

How to cite this article: Savage, C.J., Fransman, L., Jenkins, A.K. \& Bamford, C.G., 2014, 'Developing Walvis Bay Port into a logistics gateway for southern Africa: Issues, challenges and the potential implications for Namibia's future', Journal of Transport and Supply Chain Management 8(1), Art. \#154, 10 pages. http://dx.doi. org/10.4102/jtscm.v8i1.154

\section{Note:}

This article is based on a previous article published by, C.J. Savage and L. Fransman, in the Journal of Language and Communication. Please see the reference list of this article to view the full reference.

\section{Read online:}

Scan this QR
code with your
smart phone or
mobile device
to read online.

Many developing countries wish to become the 'gateway' to a region or part of a continent. One strategy involves encouraging logistics cluster development. These hubs support global supply chains and may enable the economic growth of the host country through the resulting trade, as well as providing direct and indirect employment opportunities during the build and subsequent operation of the hub. Namibia intends to develop the Port of Walvis Bay to become the preferred gateway to southern Africa and the Southern African Development Community region. This article builds on research on Caribbean cluster potential and Namibian logistics to identify the potential benefits and impact on development, as well as the drawbacks and risks of such a strategy.

\section{Introduction}

The purpose of this study is to identify the potential benefits and drawbacks of Namibia developing a gateway logistics hub and will start with a discussion of Namibia, her economy and the development of the logistics industry in the country. The article will then discuss the literature on global supply chain management and how global supply chains (GSCs) can help businesses and nations achieve competitive advantage. Following this, GSCs and logistics clusters will be examined. The article will go on to outline the research methodology adopted for this study and present the key findings and discussion. The article concludes with advice on how Namibia might develop itself as a gateway using a logistics hub, whilst showing the attendant risks to her aspirations.

\section{Developing logistics hubs: An international perspective}

Dispersion of production sites as a result of globalisation, focused factories and risk aversion have led to an increase in the flow of physical goods, financials and information across the world (Savage \& Fransman 2014):

\begin{abstract}
Specialized globalized supply chains are needed to support these operations. Flow management within the logistics pipeline has become part of a company's strategic weaponry used to meet the differing, and often volatile, demands of customers. Customer freedom of choice and increased new product launches have intensified the competition between global corporations, so they insist on a very high level of service from their supply chains. When a region espouses global supply chains, logistics activities can become a factor in its development strategy and thus influence public policy. Planners, especially those in developing countries with limited manufacturing, tend to rely on trade to enhance their economies. (Savage \& Fransman 2014:29)
\end{abstract}

Many countries have opted to develop free trade zones or foreign trade zones (FTZs) to enhance trade and foster economic development. Essentially, FTZs are designated areas within a country that, for customs regulations, are treated as foreign territory (Gourdin 2006). These areas, or zones, are places where goods can be landed, stored and distributed without these goods incurring import duties or local taxes (Gourdin 2006). Jafza Jebel Ali Free Zone in Dubai is an example of an FTZ which is serviced by more than 170 shipping lines and has the capacity to handle 15 million containers annually (see http://www.jafza.ae). According to Jacobs and Hall (2007), Dubai has managed to take advantage of its strategic location between east and west, attracting many leading manufacturers and suppliers to the Port's FTZ and, as such, has become firmly inserted within their global supply chains:

Logistics activities generate employment and facilitate trade, which can help bring greater human well-being to their region. Global supply chains offer countries and city-states with appropriate port facilities (e.g. Singapore, Rotterdam and Panama) an opportunity to bring prosperity to their communities. (Savage \& Fransman 2014:28)

Copyright: (c) 2014. The Authors. Licensee: AOSIS OpenJournals. This work is licensed under the Creative Commons Attribution License. 
Their port-based hubs have become the cornerstone of their economic growth and a key component in their nation's attempts to achieve competitive advantage (Mangan, Lalwani \& Fynes 2008). This has inspired some regions to base their development strategy on logistics clusters. Namibia is already involved in marine transport and so could play a strategic role in GSCs by setting up such clusters. This article aims to understand the potential for Namibia to use logistics clusters as the basis for regional policy development and economic growth (Savage \& Fransman 2014). The issues and arguments put forward herein need to be viewed within the wider context of the economy of Namibia, in particular its current situation with respect to external trade.

In many respects, Namibia is a dual economy. It has a modern market sector, responsible for much of its economic wellbeing, which operates alongside a traditional subsistence sector. This is typical of other economies in sub-Saharan Africa. Namibia is a founder member of the Southern African Development Community (SADC) which consists of 14 member states and is dominated by the Republic of South Africa (RSA). It is also a member of the Southern African Customs Union with the RSA, Botswana, Lesotho and Swaziland. Through this organisation, Namibia has supported tariff-free trade on goods between member countries. This is essential if it is to take full advantage of its excellent geographical location and corridor links with other members of SADC, especially land-locked countries such as Botswana and Zimbabwe. Such countries face particularly difficult challenges when it comes to trade facilitation because having inefficient or inadequate transportation, logistics and trade-related infrastructures and services can severely impede a country's ability to compete on a global scale (Arvis 2012).

The balance between Namibia's imports and exports from 2003 to 2012 is shown in Figure 1 and, from this, the impact of the global recession becomes evident - since 2008, imports have significantly exceeded exports, leading to an adverse trading position. Exports, particularly of diamonds

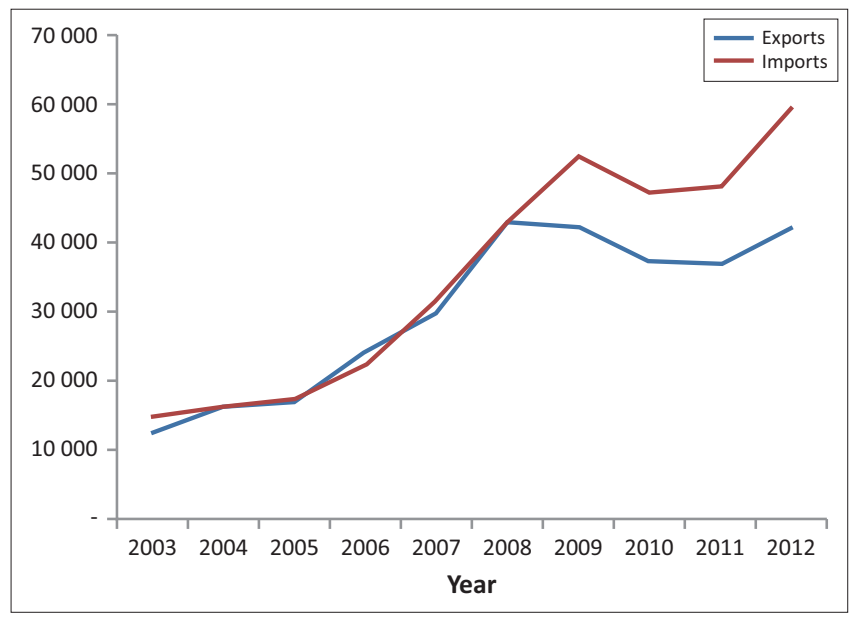

Source: Namibian Statistics Agency, 2013, Annual Trade Statistics Bulletin, Namibian Statistics Agency, Windhoek

Unit: Namibian Dollars (millions).

FIGURE 1: Namibian imports and exports, 2003-2012. and precious metals, declined, whilst the import value of manufactured goods, food and mineral fuels increased, partly in response to rising world prices. The deficits that have been incurred, along with probable projected future deficits, are likely to influence short-term to medium-term macroeconomic policies.

The economy of Namibia is inextricably linked to that of the RSA. In 2012, for example, $16 \%$ of exports and a massive $70 \%$ of imports were with the RSA (Namibian Statistics Agency 2013). Furthermore, this linkage includes the 'pegging' of the currencies (Namibian Dollar and Rand) on a one-forone basis. This means that, as the value of Rand against major currencies fluctuates, the Namibian Dollar (N\$) is also affected. For example, as the value of the Rand fell from about 10:1 to 16:1 against the British Pound between 2011 and 2013 (Rainbow Nation 2013), so too did the N\$ drastically devalue, which has affected the value of imports. Between 2011 and 2012, there was a huge increase in exports of diamonds and precious metal to Botswana; although, this may be partially the result of Gaborone's burgeoning desire to become the centre of world diamond trading (Young 2013). Trade with Angola (10\% of exports) has been more stable. Other than these three members of the SADC, the remaining exports are largely to developed economies. In contrast, Namibia's imports are largely from its local partners; although, this may be misleading, as a considerable percentage of the goods arriving from the RSA may have originated elsewhere. Developed economies, such as European Union member states and Switzerland, provide a range of manufactured goods and services; whereas, trade with China is relatively small compared to other economies in the region (Namibian Statistics Agency 2013).

Given the pattern described above, there are clear strategic reasons for developing a regional logistics hub and gateway through the Port of Walvis Bay, the largest commercial port in Namibia (and on the south-west coast of Africa). Firstly, this hub may reduce the huge dependency that Namibia has on the RSA. Simultaneously, it is likely to provide competitive pressure on RSA businesses which currently over-price and dump expensive products not only on Namibia but also on other neighbouring SADC members (Clerck 2008). Secondly, it will provide a business opportunity for the logistics operators to offer re-export and other services to business in neighbouring countries. These will, in turn, generate relevant multiplier effects and invisible export earnings to assist in reducing the negative balance of trade. The recent announcement of plans by the Zambian government to construct a road from the Namibian border to the Copperbelt represents a huge boost for the economic potential of Walvis Bay Port. The proposed route, which will reduce the distance between Sesheke and the Copperbelt by $400 \mathrm{~km}$, will reduce logistics costs and provide a new viable alternative to current export routes (Raballand \& Whitworth 2011). There is also a proposal to build a new line to transport coal from Botswana to Walvis Bay via Namibia's Gobabis railhead, bypassing Windhoek, but this is only one of a number of options being considered by Botswana's revitalised coal industry (Ash 2013). 
Most locally expressed opinion on a Namibian logistics cluster has focused on the development of Walvis Bay as a hub to facilitate import and export of goods. This has limitations because of the limited volume of goods currently needed to service Namibia's requirements and the lack of significant export volumes. An alternative that could be considered is the development of the Port as a transhipment centre. This could have the advantage of allowing Port development without further strain on the infrastructure connecting it with the hinterland. Such a strategy could support the development of the Port by increasing its revenue and, perhaps, facilitate the building of a port-centric cluster based on an added value concept. In the short term, it would not, however, provide a significant increase in trade volumes.

Another option that has been mooted is to develop a dry-port at Keetmanshoop, the capital of the Karas Region. This has been advocated recently by the governor of the region (the Honourable Bernardus Swartboois) to support goods flows from the RSA via Oranjemund and imports via the Port of Lüderitz. This is quite a new proposal, for which there is, as yet, only limited data available; furthermore, as it seems to lack both the supporting trade volume and the backing of Namibia's central government, it has not been specifically considered for this article.

\section{Global supply chain management and competitive advantage}

Global supply chains enable businesses to exploit the globalisation of economic activities (Dornier et al. 1998); for example, by accessing broader markets or developing lower cost sourcing (Ferdows 1997). They have become strategic weapons for building competitive advantage, allowing businesses to source materials and components from one place, manufacture them in another, assemble them in yet another and then to distribute them in a different territory all together. This has been made possible by trade barrier collapses, communication technology advances (Hülsmann, Grapp \& Ying 2008) and the combination of three interrelated processes: global sourcing, global manufacturing and global distribution (Bello, Lohtia \& Sangtani 2004). Businesses trade in disparate geographical regions using 'glocalisation' (think globally, but act locally) to tailor their services and/ or products to meet local needs whilst ensuring overall international governance (Swyngedouw 2004) (also see Savage \& Fransman 2014:29).

Supply chain integration has become a source of competitive advantage for both members and users by enabling goods to flow without restrictions. Supply chain management or, 'managing relationships with upstream and downstream suppliers and customers to deliver superior customer value at less cost to the entire system' (Christopher 2011:3), plays an important part in customer-oriented business strategies. When setting up any supply chain, one must integrate all internal and external resources to meet customer demand (Rota-Franz, Thierry \& Bel 2001). On a global scale this becomes very difficult, especially as to achieve efficiency, logistics processes must be executed simultaneously rather than sequentially. As these supply chains extend globally, there is a commensurate increase in the risk levels as the multiplier effect acts on the interrelation of global supply chains and their nodes (Geary, Disney \& Towill 2006) (also see Savage \& Fransman 2014:29).

The numerous flows in global supply networks harness logistics activities (e.g. consolidation, distribution, transportation, light assembly and postponement) to create value for customers. To achieve overall effectiveness, the individual activities must be effective, efficient and integrated. They also need support, which has the potential to create jobs, enhance skills and improve the population's well-being. Recognising the critical role played by logistics activities, some governments, such as China (Shenzhen) and Egypt (Damietta), have built logistics clusters to develop their countries by encouraging global supply chains (also see Savage \& Fransman 2014:29).

\section{Clusters and network integration}

A cluster can be defined as 'geographic concentration of interconnected companies, specialised suppliers, service providers, firms in related industries, and associated institutions [e.g. universities, agencies and trade associations] in particular fields that compete but also cooperate' (Porter 2000:15). The interdependency of clusters strengthens the products and/or services provided (Ketels 2003) (also see Savage \& Fransman 2014:29).

Clusters augment competitive advantage by enhancing productivity, driving innovation and contributing to the emergence of new business (Porter 1998). They develop where geographical location gives a comparative advantage, whether contained within a single city or sprawled across international borders. Literature recognises three types: the techno cluster, the historic know-how-based cluster and the factor endowment cluster (Maskell 2001). Logistics clusters tend to be of the factor endowment type; they are:

regions with a very high concentration of logistics activities relative to local population or economy [and] an amorphous agglomeration of companies and facilities with logistics-intensive operations with fuzzy borders and no central management. (Sheffi 2012:79, 81)

Basically, they are zones where operators and all activities relating to the transport, logistics and distribution of goods, are gathered together (also see Savage \& Fransman 2014:29).

Known as 'Logistics Villages' in Germany, 'Distribution Parks' in Japan and 'Logistic Centres' in the Czech Republic and some European countries (Kampf, Průša \& Savage 2012), clusters play a strategic role in GSC management by synchronising logistics flow activities. Clustering and developing network integration processes enable regions or countries to become strategic nodes in GSCs (Bosona \& Gebresenbet 2011). This induces collaboration in logistics clusters built on, and motivated by, economic benefits, 
power, trust and information sharing (Groothedde, Ruijgrok \& Tavasszy 2005). Logistics clusters integrate three core components: compound logistics and transportation services, supported industries and, critically, the group of institutions responsible for fostering their arrangement and positive evolution (Sheffi 2012) (also see Savage \& Fransman 2014:30).

\section{Global supply chains and logistics clusters}

The emergence of logistics clusters has been partially driven by the need to manage supply chains during turbulent times. Successful management of these increasingly complex chains, crucial to multinational businesses, calls for high levels of functional and organisational integration (Krajewski et al. 2003). Logistics employs powerful IT systems to manage global flows and reduce distance by saving time. Accelerating physical, informational and financial flows enables multinationals to satisfy their customers' need for time-based competition (Blackburn 1991). Organisations that are unable to deliver their goods at the right time and at the right price are likely to suffer at the hands of global competitors (Handfield \& Nichols 1999). So, today's GSCs must be hyperflexible to face the increasing level of volatility (Christopher \& Holweg 2011). Their construction constitutes a major challenge for corporations. Their networks must be designed to shorten the time-to-market for their products and build risk avoidance (Handfield \& Nichols 2002). To make GSCs more flexible, agile and resilient, corporations have begun to concentrate their logistics activities into a few strategic and innovative nodes (logistics clusters) (also see Savage \& Fransman 2014:30).

In response, some governments give their strategic regional development programmes a logistics and supply chain 'bent', making heavy investments in an effort to attract clusters to their territories. Thus, valuable collections of resources are set up by regional authorities to bring local benefits, as well as to support the world supply chain and logistics community (also see Savage \& Fransman 2014:30).

\section{Research method and design Procedure}

This research examined the concept of investing in logistics hubs as a tool for national economic and social development in Namibia. To achieve this aim, the overall methodology required three phased objectives. Firstly, to establish a baseline view of the current state of logistics in Namibia; secondly, to understand the general requirements and potential benefits of such a strategy; and, finally, to apply the data from the first phase to the criteria established during the second phase, with a view to assessing Namibia's capabilities, risks and opportunities.

\section{Phase 1 - State of Namibian logistics}

As published information on the state of the logistics industry in Namibia was limited, this research adopted a critical realism approach to examine tendencies rather than laws, looking at entities, events and experiences regarding perceptions and reality to assemble its data. Explorative research was carried out, based on 25 semi-structured interviews with key stakeholders to produce a complex matrix, analysing similarities or differences by row or column, as proposed by Nadin and Cassell (2004). The initial research was disseminated in the form of academic papers, journals (Savage, Fransman \& Jenkins 2013) and practitioner workshops. The comments from these, together with further interviews and feedback from stakeholders, were analysed and used to modify and develop the primary input data on the state of logistics in Namibia for this article (also see Savage \& Fransman 2014:30).

\section{Phase 2 - Literature review}

In this phase, literature on the potential benefits, drawbacks and risks of a logistics hub strategy were synthesised from previous work on international case study examples (Lambourdiere, Savage \& Corbin 2012; Muñoz \& Rivera 2010). This phase focused on secondary data obtained from a range of literature sources on logistics hubs and clusters. As there is a dearth of published research and information on logistics hubs in Namibia, this phase of the research concentrated on developing logistics hubs in North America, Central America, the Middle East and Asia.

\section{Phase 3 - Assessment}

Applying the Namibian data from Phase 1 to the requirements from Phase 2 allowed a comparison of Namibia's opportunities for development with those of states that have successfully adopted logistics cluster development as a regional policy. Such an assessment aimed to establish the benefits and risks of embarking on such a strategy.

\section{Results}

\section{The role of logistics clusters in global supply chains: What could it mean for Namibia?}

Namibia's most recent government regional development plan (NDP4) specifically cites logistics as one of the four 'economic priorities' (Republic of Namibia 2012). This also aligns with the proposed SADC Transport Sector Plan, part of the regional infrastructure development master plan, which focuses on four areas: improving access to the transport corridors value chain, reducing transportation costs, improving competitiveness and providing secure and safe transport services (AllAfrica 2012).

Southern Africa's logistics is dominated by the RSA; because of its size, developed infrastructure and skills, the RSA has long been accepted as the gateway for southern Africa (Cilliers \& Nagel 1994). Approximately 80\% of Namibia's total imports come from or through the RSA (African Development Bank 2007). Moreover, as stated earlier, the RSA continues to exercise a great deal of pressure on Namibia through restrictive commercial practices (Clerck 2008) (also see Savage \& Fransman 2014:31). Many Namibian logistics stakeholders want to change this situation and feel that Namibia has an opportunity to take over the gateway 
role. This is based on the country's geographical position, her ports, basic infrastructure, relative freedom from congestion and a belief that it is easier to do business through the Port of Walvis Bay than other southern African ports (Savage, Fransman \& Jenkins 2012) (also see Savage \& Fransman 2014:31). Namibia has established corridors (TransKunene, TransKalahari, TransOranje and Walvis-Bay-NdolaLubumbashi [TransCaprivi]) that provide links to countries including the RSA, Botswana, Zambia, Angola and the Democratic Republic of Congo. These are championed by the Walvis Bay Corridor Group, the key function of which is to facilitate trade via the corridors; their success is indicated by the volume of goods moving along the corridors, which grew by 33\% between 2005 and 2009 (World Bank 2012).

Successful GSCs require value-added supply chain management activities, as well as physical movement of goods. As logistics clusters can meet both requirements, they can create jobs at all levels for themselves, as well as secondary and supporting industries. Thus multinational corporations use clusters to manage their supply chains through functions such as supply chain or global networks design (from third-party or fourth-party logistics service providers), logistics information technology, kitting, postponement, et cetera. Because they bring resources, people, skills and investment into close proximity, clusters can also promote the development of new, advanced logistics services.

Developing an advanced logistics cluster in Namibia could provide much-needed services for corporations, thus encouraging investment for infrastructure improvement, enabling industrial skills capacity building and stimulating trade. By doing so, it could enhance the location's capabilities and potentially support Namibia's aspirations to make the gateway concept a reality (also see Savage \& Fransman 2014:31). This would suggest that the case for a logistics hub is so positive as to be axiomatic, but, even if everything were to be developed successfully, there are concomitant risks.

The relationship between transport infrastructure investment and economic development has been the subject of many empirical investigations in both developing and developed economies. Superficially, the relationship ought to be positive; that is, that new investment in ports, railways and roads generates economic growth over time. This comes about through increased productivity of businesses in a region, enhanced innovation and the attraction of new firms to the region. Bergman and Feser (1999) built upon Porter's (1998) earlier work by showing how industrial clusters could link together the various strands of regional policy to generate economic development.

The evidence of such a relationship is by no means overwhelming. An alternative view is of an endogenous relationship, namely that transport infrastructure investment should take place only when the demand is there. In other words, once economic development within a region is taking place, new roads, railways and port facilities will give a further boost to an emerging vibrant regional economy. For developing economies, this will, in turn, promote the regular flow of labour to urban areas over time, unlike the alternative approach, which can produce a chaotic and uncontrolled flow of population, aggravating social problems and the impoverishment of rural communities.

The significance of this argument for Namibia's proposed logistics hub at Walvis Bay is not easy to assess. The positive relationship is more evidenced in developing economies than in those that are developed. This is largely accounted for by the complexity of economic relationships and linkages in the latter. At the same time, the opportunity cost should be acknowledged. For example, if public sector funding is used for Walvis Bay then this means that the additional resources involved will have to be taken from other areas of government funding. Given the present state of Namibia's economy, many risks and uncertainties are involved. The cost of taking no action, though, is one that may well be regretted later.

Findings of stakeholder 2013-2014 surveys into 'barriers to the development of the Namibia logistics industry' (Savage et al. 2014:n.p.) shows that there is considerable optimism in Namibia's ability to implement and operate the proposed port-centric logistics hub and that this could, in turn, enable economic development. Sadly, however, the same survey suggests that there is considerable doubt that the income would be used to aid social development or address the very high Gini index, which currently stands at 0.59 (Namibian Statistics Agency 2012) by cascading of wealth down to the mass of the populous.

\section{Requirements for successful logistics cluster development in Namibia}

In order to evolve into successful entities, logistics clusters need to have a sound framework, built on solid foundations. Following research on Singapore, Dubai and Panama clusters, Muñoz and Rivera (2010) have identified a number of critical factors needed for a successful logistics cluster strategy (also see Savage \& Fransman 2014:32). These are, (1) a strategic location, (2) government commitment and stability, (3) human resources, (4) infrastructure, (5) administrative processes, (6) regulation and (7) anchor businesses and foreign direct investment attraction (see Table 1). It should be noted that some factors (e.g. geography) are pre-existing or naturally occurring and so are beyond the control of planners. Nevertheless, like a building, this strategy has three parts the foundation, pillars and a capstone.

\section{The foundation - Strategic location, government commitment and stability}

To work, logistics clusters must have an appropriate location and the support of a policymaker (i.e. the foundation should build on the location's benefits only where government support is assured). Both of these factors are needed; a good strategic location alone will not guarantee success because neither supply chain professionals nor investors will commit 
TABLE 1: Key elements of clusters.

\begin{tabular}{|c|c|c|c|c|}
\hline Cluster elements & Singapore & Dubai & Panama & Panama planned \\
\hline Strategic location & $\begin{array}{l}\text { Strategic position in the Asian } \\
\text { north-south corridor. }\end{array}$ & $\begin{array}{l}\text { Strategic position between } \\
\text { Europe and Asia. }\end{array}$ & $\begin{array}{l}\text { Strategic position allowing } \\
\text { transition from Pacific to Atlantic } \\
\text { Oceans. }\end{array}$ & $\begin{array}{l}\text { Expansion of the Canal will ease } \\
\text { current ship size restrictions } \\
\text { providing more capacity for } \\
\text { connectivity. }\end{array}$ \\
\hline Political stability & $\begin{array}{l}\text { Committed and stable government. } \\
\text { Unique party. }\end{array}$ & $\begin{array}{l}\text { Committed and stable } \\
\text { government. Unique party. }\end{array}$ & $\begin{array}{l}\text { Committed government. Multiple } \\
\text { political, parties, potential } \\
\text { opposition. }\end{array}$ & $\begin{array}{l}\text { Long-term policies and laws to } \\
\text { protect investors. }\end{array}$ \\
\hline Human capital & $\begin{array}{l}\text { Emphasis on logistics and technical } \\
\text { education, world class labour force. }\end{array}$ & $\begin{array}{l}\text { Incentives to bring labour from } \\
\text { other countries and provide } \\
\text { world class labour force. }\end{array}$ & $\begin{array}{l}\text { Inadequate labour force, lack } \\
\text { of technical knowledge. }\end{array}$ & $\begin{array}{l}\text { Investments in logistical } \\
\text { education and technical training. }\end{array}$ \\
\hline Infrastructure & $\begin{array}{l}\text { World class infrastructure and } \\
\text { intermodality. }\end{array}$ & $\begin{array}{l}\text { World class infrastructure and } \\
\text { intermodality. }\end{array}$ & $\begin{array}{l}\text { Good ports, lack of proper } \\
\text { intermodality. }\end{array}$ & $\begin{array}{l}\text { Expanded canal and ports. } \\
\text { Improvements in road } \\
\text { connectivity. }\end{array}$ \\
\hline Administrative processes & $\begin{array}{l}\text { World class customs, and other } \\
\text { relevant business processes. }\end{array}$ & $\begin{array}{l}\text { Investor friendly legislature. } \\
\text { 'Freeport' availability. }\end{array}$ & $\begin{array}{l}\text { Denoted as corrupted, and not } \\
\text { as efficient. }\end{array}$ & $\begin{array}{l}\text { 'One-stop-shop' type of entity } \\
\text { new business creation. }\end{array}$ \\
\hline
\end{tabular}

Source: Muñoz, D. \& Rivera, M.L., 2010, 'Development of Panama as a logistics hub and the impact on Latin America', MEng thesis, Engineering Systems Division, Massachusetts Institute of Technology

themselves to cluster development unless they believe that the project has a long-term future. This requires commitment to the location from the government, planners, logistics service providers and financiers, as well as local businesses and international traders. Significant social buy-in to win 'hearts and minds' in order to encourage public and private institutions to support the development is also critical.

\section{The pillars - Human resources, infrastructures, administrative processes and regulations}

Pillars are essential for support and, in this case, they include: human resources, infrastructure, regulation and administrative processes. Human resources play a strategic role in cluster sustainability. In addition to recruitment, they must ensure that quality logistics and supply chain management education is available to train 'home grown' staff to fill crucial positions. This aims to improve the workers' transferrable management skills, as well as their technical knowledge, so that they can be integrated into professional supply chain networks.

Physical (logistics) infrastructure is the clusters' 'hardware', needed to move goods, from town to town and county to county. Efficient logistics infrastructure enables rapid flow, but any deficiency in it can ruin service quality. International infrastructure has improved significantly and, combined with innovation, has enabled logistics service providers to operate extended GSCs successfully. Namibia has some good basic infrastructure, but it will require major development supported by cultural change to meet international requirements.

Administration is another important pillar. Effective flows rely on 'just-in-time' principles, so any process delay or error could inhibit the movement of goods and thus compromise global supply chains. Namibian regional authorities should support initiatives such as electronic customs' clearance systems, harmonisation (and simplification) of administration requirements and improved application of internationally agreed standards; essentially anything that enhances service.

Although there are 'good pockets', administration is an area of general, and quite severe, weakness in Namibia, where siloism and inflexibility abound. It is crucial to avoid gaining entry to GSCs only to be unable to maintain or consolidate one's position within them. This can be fatal, as, rather than developing and moving up the service hierarchy, businesses could lose existing customers. A regional development policy with logistics clusters at its heart cannot afford to underestimate this risk, because GSC managers require very high standards of service and flexibility.

Regulation sets the climate for business operation and development. Logistics clusters must attract business, so a friendly and efficient regulation atmosphere is essential. A long-term view of jurisprudence is required so laws remain stable over a sustained period and are applied equally to every agent or corporation without discrimination. Poor regulations can have an insidious impact on competition and discourage inward investment or cluster participation. Namibia must avoid deterrent regulatory approaches, but espouse those that deal with anticompetitive behaviour. The business climate should be 'free of burdens' and enable opportunities for new logistics firms, as well as providing incentives for existing organisations to innovate and improve their productivity. 'Tax' is another difficult regulatory area, as maximum revenue is needed to develop infrastructure and facilities, but high or inequitable taxes or difficult compliance will reduce profits thus discouraging entry.

Poor regulatory climates are bad for potential logistics clusters because they deter entry and have a severe impact on productivity and growth. Namibia must identify and address any underlying problems if she wishes to use logistics clusters to improve her investment climate and encourage foreign direct investment rather than corruption.

\section{The capstone - Incoming businesses}

The capstone of a logistics cluster is built by overseas businesses that have effective GSC management strategies. Often 'bench mark innovators' in marketing or logistics, these businesses have a proven ability to attract others to a cluster's facilities; encouraging them is vital for cluster development and growth. Once in place, such logistics business conglomerates hold the pillars together and thus 
TABLE 2: Applying to Muñoz and Rivera's criteria for logistics cluster success to Namibia.

\begin{tabular}{|c|c|c|}
\hline Criteria & Namibia & Classification against criteria \\
\hline Strategic location & $\begin{array}{l}\text { Strategic position on the coast of south-west Africa, with connections to global shipping routes } \\
\text { giving access to the SADC countries. }\end{array}$ & $\begin{array}{l}\text { Excellent - but, some risk as there are other } \\
\text { competitors. }\end{array}$ \\
\hline Political stability & $\begin{array}{l}\text { Since independence from the RSA in } 1990 \text {, the political situation has been stable with an } \\
\text { elected government. The recently published National Development Plan } 4 \text { sets logistics } \\
\text { and infrastructure as important priorities. }\end{array}$ & Good - provided intentions become actions. \\
\hline Human capital & $\begin{array}{l}\text { There is a perceived (and real) lack of logistics training, education and qualified staff. } \\
\text { In addition, there is a lack of understanding of the concepts of international service standards } \\
\text { and a reluctance to conform to them. }\end{array}$ & $\begin{array}{l}\text { Poor-education can be improved but time is } \\
\text { needed. Further, the attitude issue may be a 'deal- } \\
\text { breaking' stumbling block. }\end{array}$ \\
\hline Infrastructure & $\begin{array}{l}\text { The Port of Walvis Bay has a good strategic location, but the present container capacity } \\
\text { ( } 250000 \text { TEUs) is a limitation. This has been recognised and there are plans to enlarge to } \\
\text { up to } 1 \text { million TEUs, but recent (2011-2012) congestion suggests that the supporting road } \\
\text { infrastructure may become a limiting factor. There is a rail network, but it is narrow gauge and } \\
\text { is considered to be expensive and unreliable, so its use for freight tends to be very limited. } \\
\text { The small size of the population, together with the vast geography of the country, makes the } \\
\text { investment in and maintenance of transport infrastructure very difficult. }\end{array}$ & $\begin{array}{l}\text { Fair - there is potential, but major investment and } \\
\text { time will be required. }\end{array}$ \\
\hline \multirow[t]{2}{*}{ Administrative processes } & $\begin{array}{l}\text { This is a contentious area for, whilst the Walvis Bay Corridor Group state that 'turnaround } \\
\text { times for offloading vary from } 12 \text { to } 15 \text { hours for container vessels; } 24 \text { to } 48 \text { hours for bulk } \\
\text { vessels, depending on tonnage and shipment; and between } 18 \text { and } 20 \text { hours for break-bulk } \\
\text { vessels'. Logistics stakeholders say that, 'There are customs issues and delays'. Additionally } \\
\text { operators and users claim that, 'Border control paperwork is cumbersome and goods } \\
\text { (including fresh foodstuffs) are often held at the border too long because of the submission of } \\
\text { paperwork' and 'charges are applied at the borders (e.g. by Botswana and Zambia)'. }\end{array}$ & $\begin{array}{l}\text { Mixed (fair to poor) - the optimism of the } \\
\text { corridor groups is commendable. But the general } \\
\text { attitude, especially in the Parastatals will have to } \\
\text { be addressed and changed. }\end{array}$ \\
\hline & $\begin{array}{l}\text { In general, Namibian administration is characterised by bureaucracy, duplication and siloism, } \\
\text { where individuals operate in a vacuum and lack any awareness of the upstream } \\
\text { or downstream processes that surround them. }\end{array}$ & \\
\hline $\begin{array}{l}\text { Regulations for attracting } \\
\text { foreign direct investment }\end{array}$ & $\begin{array}{l}\text { There is a history of attracting inward investment from countries such as China, the USA } \\
\text { and Germany, but results have not always lived up to expectations. }\end{array}$ & $\begin{array}{l}\text { Average - the scope is there, but whether it can } \\
\text { be capitalised on fully remains to be seen. }\end{array}$ \\
\hline Anchor businesses & Several logistics service providers, such as Transworld Cargo and DHL, are established locally. & $\begin{array}{l}\text { Average - there is scope, but it will only be } \\
\text { developed if the companies feel that the other } \\
\text { criteria are met. }\end{array}$ \\
\hline
\end{tabular}

Source: Criteria adapted from Muñoz, D. \& Rivera, M.L., 2010, 'Development of Panama as a logistics hub and the impact on Latin America', MEng thesis, Engineering Systems Division, Massachusetts Institute of Technology

SADC, Southern African Development Community; RSA, Republic of South Africa; TEUs, twenty-foot equivalent units.

help to guarantee the success of the development (also see Savage \& Fransman 2014:31)

\section{Namibian compliance and risks that could frustrate a logistics cluster strategy}

Perceived Namibian compliance based on the present state, as determined by this research, is illustrated in Table 2. This shows that the spectrum of issues is broad and of varying seriousness and difficulty. Significant examples of these issues are discussed in the subsections below.

\section{Socio-economic dynamics}

Socio-economic dynamics (possibly resulting from decolonisation and independence) may be considered to be constraints to development. For example, because atavisms are retained in supply chains, social cohesion and trust are low. This is illustrated by the poor relationship between public (including parastatal) and private sectors (Jenkins, Fransman \& Savage 2012). This constrains the public-private dialogue needed to encourage the development of logistics clusters. Government policy, when enacted, has often protected certain groups' or organisations' power to the disadvantage of others. A regional development policy with logistics at its heart should neither inhibit original thinking and new business creation, nor restrict it to 'approved sections of the community'. Government strategy for logistics clusters should be underpinned by innovation, entrepreneurship and competitiveness; it should not encourage nepotism on a personal, family or tribal basis. Tribalism is acknowledged as frustrating and stunting democracy (Juma 2013), but its impact on business development may be overlooked (also see Savage \& Fransman 2014:33).
Namibian recruitment advertisements often state that 'preference will be given to a Namibian candidate'. Done in the name of capacity building and theoretically laudable, this is thinly disguised nepotism where the ability to do the job may be of relatively low importance. A similar principle is often applied to the awarding of business where, despite 'competitive tendering', preference will usually be given to a proposal that will benefit the service buyer personally. Rather than being seen as corrupt, this is simply regarded as 'normal business practice'.

\section{Governance, business attitudes and communication}

Namibia has the advantage of being a self-governing single state, but its businesses, influenced by tribalism, are fragmented and tend to work on a transactional or even adversarial, rather than on a collaborative or partnership basis. Furthermore, both business and state still tend to be influenced or even dominated, by the RSA (Cilliers \& Nagel 1994). Therefore, the level of business or logistics collaboration strategy in Namibian supply chains is low. Her companies tend to be in 'rent-seeking' or 'win-lose' business relationships, which tends to increase the logistics and supply chain costs (also see Savage \& Fransman 2014:34).

Technical and financial supply chain management skills essential to improving the level of supply chain integration are not well represented in the Namibian education system. This is being addressed (e.g. by the Polytechnic of Namibia), but is a slow process. High volume trading links to businesses in the other SADC states are not sufficiently established and many tend to be transactional rather than partnership-based. International infrastructure, such as nodes, dry ports and, in particular, the links between them, are still limited; for example, 
the rail link between Walvis Bay and the north of Namibia is seen as inefficient, so stakeholders would rather use roads, even for low value, high volume goods. This is exacerbated by support services such as customs cooperation, which is still felt to be counterproductive and not to engender efficient supply chain transactions (World Bank 2012). Difficulties with language and literacy prevent the use of uniform goods labels across the region and cause communication issues. Namibia has some 14 tribal groups, speaking 26 languages (Namibian Tourist Board 2013). Although Oshiwambo is the first language of about half of the 2.3 million population, Afrikaans is the lingua franca, German is common in some areas and English is the official state language. Unfortunately, English is often spoken, written and read poorly, which leads to inaccuracy, misunderstanding and delays (also see Savage \& Fransman 2014:34).

\section{Supply chain risk}

Increasing the length of a supply chain implies adding nodes and links, which magnifies complexity and risk as a result of the mathematical multiplier effect. Therefore, because any new logistics cluster or other form of node must be able to guarantee that their operation will be free of disruption, risk assessment and mitigation should be incorporated into their design. They should foster feedback and iteration giving kaizen-type continuous improvement (Schlegel \& Trent 2012). Consequently, Namibian policymakers should fully understand the issues and recognise that they, and any cluster members, need guidelines and procedures to ensure that disruption is avoided or swiftly rectified so that supply chains are resilient (also see Savage \& Fransman 2014:34).

Today's global village is a very competitive one and businesses with existing supply chain structures will endeavour to preserve the status quo. It is not unheard of for powerful governments to impose trade restrictions or tariffs if they feel that their business interests are under threat (Savage \& Griffiths 2007). Such econo-political risks must also be assessed before the Namibian government commits itself to any new logistics cluster development.

\section{Service}

Global players demand levels of service and efficiency that enhance rather than frustrate the high speed flow of goods. Such exacting standards appear completely alien to the Namibian psyche and may pose the ultimate stumbling block (Savage et al. 2012) (also see Savage \& Fransman 2014:34).

\section{Discussion}

\section{Some concepts for a southern African logistics cluster blueprint}

The construction of a Namibian logistics cluster could mean opportunities for new social development and improved physical goods flow in the SADC region. To succeed, this policy requires a radical change in Namibia's strategic planning approach and, perhaps more importantly, culture (also see Savage \& Fransman 2014:34). Global supply chains, the raison d'être for nodes, need smooth logistics flows. To achieve this, clusters (the nodes) integrate strategically important, value-adding logistics functions that can service GSCs at local, national, regional or global level and adapt their functions to suit frequently changing requirements. Exploiting logistics flows can enhance the growth and development of a territory's regional economy, but to enable the rise of clusters for concomitant job creation, Namibia will need strong social cohesion (the software of social territorial structure). Achieving positive outcomes from a logistics-based regional planning policy will require the development of a serious network culture. Therefore, Namibia's government needs an holistic approach because logistics clusters require trust between the public and private sectors, huge investment, a dramatic change in culture and cooperation up and down the supply chain, even extending into neighbouring countries. They will need to use logistics professionals to play advisory and facilitation roles and, consequently, heed their advice. Their policies should promote a healthy 'what's-in-it-for-we' approach rather than a 'what's-in-for-me' one (Vitasek, Ledyard \& Manrodt 2010). Clusters should be places where businesses will find logistics outsourcing services and symbiotic relationships that encourage collaborative strategies. Namibia needs a culture where local, regional and global supply chains work together using clusters to build demand driven services for the SADC region.

Detailed market research will be needed to identify the volume and value of existing and potential trade that could benefit from and support logistics hub infrastructure. It will also be needed to determine how to develop the concept of logistics clusters for Namibia, based on integration, collaboration, agility and suppleness. As a starting point, the following rules adapted from those proposed by Wilson and Doz (2012) for an innovative logistics cluster-based strategy can be applied. These are, (1) understand the cultural, financial, technical and other requirements, (2) start small, (3) use rigorous project management with seasoned logistics project leaders, (4) invest time defining the innovation needed to offer an unique selling point for Namibia as the gateway to the region, (5) build enough knowledge overlap to enable collaboration and (6) avoid relying solely on technology for communication.

Under pressure from fierce global competition, executives, entrepreneurs and investors seek places where the location is 'right' and logistics innovation is taking place. There are opportunities for Namibia to provide a logistics hub for her region, but to succeed, she must understand the issues and be willing to address them (also see Savage \& Fransman 2014:35).

\section{Conclusion}

Global supply chain management facilitates the movement of goods, information and financials through space and time. Nodes should be 'switching points' that enable goods to be directed via the most effective and efficient route available. Successful logistics hubs can form a gateway to a country 
or region. The services they and their clustered businesses provide facilitate the movement of goods and add value through technical activities that benefit both producers and consumers in a cost-effective way. By doing so, these hubs can facilitate economic development, but only if there is sufficient existing or potential trade.

Where the necessary criteria are satisfied, hubs and clusters are able to form a plank of a region's strategic development policy by providing high value-added logistics services to multinationals. International businesses seek competitive places to install logistics facilities where they can be sure that functional and geographical integration of their GSCs can be accomplished. As well as serving the supply chain, such facilities can improve national competitiveness; for example, Singapore's sustainable economic growth was underpinned by logistics clusters. Efficient logistics clusters can enhance a territory's economic growth and be a geopolitical weapon that improves their strategic competitiveness by offering positional benefits for GSCs. Namibia would like to attract corporate logistics functions to benefit itself and service the SADC region (also see Savage \& Fransman 2014:43).

This article suggests that, whilst the vision is appealing, there are some pitfalls and, as Craig (2013:n.p.) states: 'many locations have invested in infrastructure but have failed at being the logistics hub'. It suggests that identifying and implementing 'remedies' for shortcomings must be part of Namibia's logistics clusters development or the whole concept could implode, fail and have an overall negative impact on the country (and the region). It should be remembered that there are substantial risks in developing a logistics hub. The case of the Jade Wesser port in Germany (Weber 2003) is a pertinent reminder that such projects can fail to attract significant cargo volumes. Whilst Germany can afford a failed logistics hub, the adverse impact of failure on the financial and social facets of a much smaller economy, such as Namibia's, is significantly greater.

Logistics clusters are places where innovation and learning are vital components, which together with the close proximity of suitable commercial, physical and academic institutions can form a virtuous spiral. If developed and run successfully, a Namibian logistics cluster project could prove to be the catalyst for increased trade leading to the country's economic and social advancement.

As little has been written regarding gateway logistics hubs in Namibia, this article, it is hoped, will contribute to knowledge and understanding on this important topic. In order to progress research into the feasibility of developing gateway logistics hubs in Namibia, it is recommended that further research be undertaken. This could take the form of undertaking additional interviews or focus groups with key stakeholders, such as shipping companies. It might also be fruitful to undertake quantitative research in the form of a survey with a diverse range of stakeholders. Invariably, a limitation of undertaking research into logistics in Namibia is the lack of statistics. The state of logistics research, mentioned earlier in this article, has attempted to address this limitation. However, there is still much to learn about logistics in Namibia.

It is said that Namibians always 'make a plan', albeit often at the last minute, and make things work. To become a successful gateway, they will need to adopt a detailed longterm approach accompanied by a significant change in attitude to service. If successful, this could lead to higher rates of growth and prosperity for the populace, but anything less than a controlled and wholehearted approach may fail. As noted above, the early introduction of sophisticated infrastructure, such as a logistics hub, does not guarantee a concomitant improvement in productivity or the economy. Such premature investment before the existence of proven demand can lead to chaos and social problems, rather than the hoped for boost in innovation and trade. Taking all of these factors into consideration, it can be seen that the use of logistics hubs or clusters to develop Namibia as a regional gateway has the potential to be an economic blessing for her development. But, if not approached in a realistic, structured and comprehensive manner, it could turn out to be a costly error. This article has outlined some of the arguments in this debate, but only time can provide an incontrovertible answer to the question of feasibility itself.

\section{Acknowledgements Competing interests}

The authors declare that they have no financial or personal relationships that may have inappropriately influenced them in writing this article.

\section{Authors' contributions}

C.J.S. (Namibian German Centre for Logistics) Namibian logistics data capture and analysis; literature review and associated analysis of clusters requirements. Main article author. L.F. (Polytechnic of Namibia) Namibian data capture and analysis; article review and proofreading. A.K.J. (University of Huddersfield) Namibian literature review and proofreading. C.G.B. (University of Huddersfield) Economic research and input as well as proofreading.

\section{References}

African Development Bank, A., 2007, African economic outlook: Namibia, African Development Bank, Abidjan.

AllAfrica, 2012, SADC infrastructure plan ready for approval, viewed 15 August 2012, from http://allafrica.com/stories/201207060882.html

Arvis, J.F., 2012, Trade facilitation and logistics, World Bank, Washington, DC, viewed 28 May 2013, from http://web.worldbank.org/WBSITE/EXTERNAL/TOPICS/ EXTTRANSPORT/EXTTLF/0,,menUPK:515440 pagePK:149018 piPK:149093 theSi tePK:515434,00.html

Ash, P., 2013, 'Coal to power Botswanan revival?', International Rail Journal, 15 July, viewed 02 October 2013, from http://www.railjournal.com/index.php/africa/ coal-to-power-botswanan-revival.html

Bello, D.C., Lohtia, R. \& Sangtani, V., 2004, 'An institutional analysis of supply chain innovations in global marketing channels', Industrial Marketing Management 33, 57-64. http://dx.doi.org/10.1016/j.indmarman.2003.08.011

Bergman, E.M. \& Feser, E.J., 1999, Industrial and regional clusters: Concepts and comparative applications, WVU Regional Research Institute, Morgantown. 
Blackburn, J., 1991, Time-based competition: The next battleground in American manufacturing, Business One Irwin, Homewood.

Bosona, T.G. \& Gebresenbet, G., 2011, 'Cluster building and logistics network integration of local food supply chain', Biosystems Engineering 108, 293-302. http://dx.doi.org/10.1016/j.biosystemseng.2011.01.001

Christopher, M., 2011, Logistics \& supply chain management, Pearson Education Limited, Harlow.

Christopher, M. \& Holweg, M., 2011, 'Supply chain 2.0: Managing supply chains in the era of turbulence', International Journal of Physical Distribution \& Logistic Management 41, 63-82. http://dx.doi.org/10.1108/09600031111101439

Cilliers, W. \& Nagel, P., 1994, 'Logistics trends in South Africa', International Journal of Physical Distribution \& Logistics Management 24, 4-14. http://dx.doi. org/10.1108/09600039410070948

Clerck, G., 2008, 'Industrial relations in Namibia since independence: Between neoliberalism and neo-corporatism?', Employee Relations 30, 355-371. http://dx.doi. org/10.1108/01425450810879349

Craig, T., 2013, Why does Qatar not want to be the logistics hub of the GCC and of MENA?, Qatar Business Network.

Dornier, P., Ricardo, E., Fender, M. \& Kouvelis, P., 1998, Global operations and logistics. Texts and cases, John Wiley \& Sons, New York.

Ferdows, K., 1997, 'Making the most of foreign factories', Harvard Business Review 75, 73-91.

Geary, S., Disney, S.M. \& Towill, D.R., 2006, 'On bullwhip in supply chains - Historical review, present practice and expected future impact', International Journal of Production Economic 101, 2-18. http://dx.doi.org/10.1016/j.ijpe.2005.05.009

Gourdin, K.N., 2006, Global logistics management: A competitive advantage for the 21st century, Blackwell, Oxford.

Groothedde, B., Ruijgrok, C. \& Tavasszy, L., 2005, 'Towards collaborative, intermodal hub networks: A case study in the fast moving consumer goods market', Transportation Research: Part E 41, 567-583. http://dx.doi.org/10.1016/j. tre.2005.06.005

Handfield, R. \& Nichols., E.J., 1999, Introduction to supply chain management, Prentice Hall, Upper Saddle River.

Handfield, R. \& Nichols, E.J., 2002, Supply chain redesign. Transforming supply chains into integrated value systems, Financial Times/Prentice Hall, Upper Saddle River.

Hülsmann, M., Grapp, J. \& Ying, L., 2008, 'Strategic adaptivity in global supply chains - Competitive advantage by autonomous cooperation', International Journal of Production Economics 114, 14-26. http://dx.doi.org/10.1016/j. ijpe.2007.09.009

Jacobs, W. \& Hall, P.V., 2007, 'What conditions supply chain strategies of ports? The case of Dubai', GeoJournal 68, 327-342. http://dx.doi.org/10.1007/s10708-0079092-x

Jafza.ae, 2013, Jafza Jebel Ali Free Zone, viewed 23 September 2014, from http:// www.jafza.ae

Jenkins, A.K., Fransman, L. \& Savage, C.J., 2012, 'Logistics in Namibia: Issues and challenges', Presented at 2nd Carpathian Logistics Congress, Jesenik, Czech Republic, 07-09 November.

Juma, C., 2013, 'How tribalism stunts African democracy', BBC News: Africa, 27 November, viewed 21 January 2013, from http://www.bbc.co.uk/news/worldafrica-20465752

Kampf, R., Průša, P. \& Savage, C.J., 2012, 'Systematic location of the public logistic centres in Czech Republic', Transport 26, 425-432. http://dx.doi.org/10.3846/16 484142.2011.635424

Ketels, C.H.M., 2003, 'The development of the cluster concept - Present experiences and further developments', Prepared for NRW Conference on Clusters, Duisberg, Germany, 05 December.

Krajewski, L., Ritman, I., Mitchell, J. \& Townley, C., 2003, Management des Opérations, Pearson, Paris.

Lambourdiere, E., Savage, C. \& Corbin, E., 2012, 'Global supply chains, logistics clusters and economic growth: What it could mean to Caribbean territories?', Proceedings of the Conference on the Economy (COTE), 11-12 October, University of West Indies, Port of Spain.
Mangan, J., Lalwani, C. \& Fynes, B., 2008, 'Port-centric logistics', The International Journal of Logistics Management 19, 29-41. http://dx.doi. org/10.1108/09574090810872587

Maskell, P., 2001, 'Towards a knowledge-based theory of the geographical cluster' Industrial and Corporate Change 10, 921-943. http://dx.doi.org/10.1093/icc/10.4.921

Muñoz, D. \& Rivera, M.L., 2010, 'Development of Panama as a logistics hub and the impact on Latin America', MEng thesis, Engineering Systems Division, Massachusetts Institute of Technology.

Nadin, S. \& Cassell, C., 2004, 'Using data matrices', in C. Cassell \& G. Symon (eds.), Essential guide to qualitative methods in organizational research, pp. 271-287, Sage Publications, London. http://dx.doi.org/10.4135/9781446280119.n22

Namibian Statistics Agency, 2012, Namibia Household Income \& Expenditure Survey (NHIES) 2009/10, Namibian Statistics Agency, Windhoek.

Namibian Statistics Agency, 2013, Annual Trade Statistics Bulletin, Namibian Statistics Agency, Windhoek.

Namibian Tourist Board, 2013, Namibia's people, viewed 18 November 2013, from http://stories.namibiatourism.com.na/Portals/165392/docs/namibia's\%20 people.pdf

Porter, M., 1998, On competition, Harvard Business Press, New York.

Porter, M., 2000, 'Location, competition and economic development: Local clusters in a global economy', Economic Development Quarterly 14(1), 15-34, Sage Publications, New York. http://dx.doi.org/10.1177/089124240001400105

Raballand, G. \& Whitworth, A., 2011, 'Should the Zambian government invest in railways?', ZIPAR Working Paper 3, Zambia Institute for Policy Analysis \& Research, Lusaka.

Rainbow Nation, 2013, Rand Watch: South Africa Rand vs UK Pound, viewed 18 October 2013, from http://www.rainbownation.com/uk/compare/index.asp

Republic of Namibia, 2012, Namibia's Fourth National Development Plan (NDP4), National Planning Commission, Windhoek.

Rota-Franz, K., Thierry, C. \& Bel, G., 2001, 'Gestion des Flux dans les Chaines Logistiques', Performance Industrielle et Gestion Des Flux 1, 153-186.

Savage, C.J. \& Griffiths, J., 2007, 'Global supply chains: Saints or sinners', in T.U.O. Hull (ed.), Proceedings of the Logistics Research Network 2007 Conference (LRN2007), 05-07 September, The University of Hull, Hull, pp. 165-173.

Savage, C.F. \& Fransman, L., 2014, 'Can Namibia Become a Regional Gateway by Developing a Logistics Hub around Walvis Bay's Port?', Journal of Language and Communication 8(1), 28-46.

Savage, C.J., Fransman, L. \& Jenkins, A.K., 2012, Logistics in Namibia: Issues and challenges, Polytechnic of Namibia, Windhoek.

Savage, C.J., Fransman, L. \& Jenkins, A.K., 2013, 'Logistics in Namibia: Issues and challenges', Journal of Transport and Supply Chain Management 7, 8 pages.

Savage, C.J., Fransman, L., Bamford, C.G. \& Jenkins, A.K., 2014, 'The response of key stakeholders to the proposed Walvis Bay port-centric hub development', Presented at the 19th Logistics Research Network Conference, 03-05 September, University of Huddersfield, UK.

Schlegel, G.L. \& Trent, R.J., 2012, 'Risk management: Welcome to the new normal', Supply Chain Management Review, January/February, 12-21.

Sheffi, Y., 2012, Logistics clusters, MIT Press, Cambridge.

Swyngedouw, E., 2004, 'Globalisation or "glocalisation"? Networks, territories and rescaling', Cambridge Review of International Affairs 1, 25-48. http://dx.doi. org/10.1080/0955757042000203632

Vitasek, K., Ledyard, M. \& Manrodt, K., 2010, Vested outsourcing: Five rules that will transform outsourcing, Palgrave Macmillan, New York.

Weber, J., 2003, 'The project of the new Jade-Wesser port', Traffic Policy Review 15, 271-275.

Wilson, K. \& Doz, Y.L., 2012, '10 Rules for managing global innovation', Harvard Business Review 90(10), 84-90.

World Bank, 2012, Regional transport \& trade logistics in Namibia: World Bank policy note, World Bank, Windhoek.

Young, R., 2013, 'Botswana: From sleepy backwater to global diamond hub', BBC News: Business, 20 August, viewed 17 October 2013, from http://www.bbc.co.uk/ news/business-23771552 